IZA DP No. 6749

Do Employees Profit from Profit Sharing? Evidence from Canadian Panel Data

Richard J. Long

Tony Fang

July 2012 


\title{
Do Employees Profit from Profit Sharing? Evidence from Canadian Panel Data
}

\author{
Richard J. Long \\ University of Saskatchewan
}

Tony Fang
York University

and IZA

\section{Discussion Paper No. 6749 \\ July 2012}

IZA

P.O. Box 7240

53072 Bonn

Germany

\author{
Phone: +49-228-3894-0 \\ Fax: +49-228-3894-180 \\ E-mail: iza@iza.org
}

\begin{abstract}
Any opinions expressed here are those of the author(s) and not those of IZA. Research published in this series may include views on policy, but the institute itself takes no institutional policy positions.

The Institute for the Study of Labor (IZA) in Bonn is a local and virtual international research center and a place of communication between science, politics and business. IZA is an independent nonprofit organization supported by Deutsche Post Foundation. The center is associated with the University of Bonn and offers a stimulating research environment through its international network, workshops and conferences, data service, project support, research visits and doctoral program. IZA engages in (i) original and internationally competitive research in all fields of labor economics, (ii) development of policy concepts, and (iii) dissemination of research results and concepts to the interested public.
\end{abstract}

IZA Discussion Papers often represent preliminary work and are circulated to encourage discussion. Citation of such a paper should account for its provisional character. A revised version may be available directly from the author. 


\title{
ABSTRACT
}

\section{Do Employees Profit from Profit Sharing? Evidence from Canadian Panel Data}

\begin{abstract}
Using panel data from a large sample of Canadian establishments, this paper examines whether employee earnings increase, decrease, or do not change in the period subsequent to adoption of profit sharing, relative to establishments that do not adopt profit sharing. Our research contributes to knowledge by utilizing longitudinal analysis to assess the effects of profit sharing adoption on employee earnings growth within a carefully constructed sample of Canadian establishments, and by assessing both cash real earnings growth and total real earnings growth, while controlling for a wide array of variables that may affect these results. On average, employees in Canadian establishments that adopted profit sharing during 19992001 appeared to benefit from the introduction of profit sharing, in terms of both their cash real earnings growth and total real earnings growth, in the five-year span following introduction of profit sharing. This advantage was both statistically and practically significant, adding about 15 percentage points to real employee earnings growth over the five-year period, a period during which employee earnings growth was generally modest.
\end{abstract}

JEL Classification: J33, J31, J38

Keywords: $\quad$ profit sharing plans, employee earnings, firm-worker linked survey, Canada

Corresponding author:

Tony Fang

School of Human Resource Management

York University

4700 Keele Street

Toronto, Ontario M3J 1P3

Canada

E-mail: tonyfang@yorku.ca 
Although employee profit sharing is a pay practice that has a long history (Coates 1991), and one that many firms continue to adopt (Lawler, Mohrman and Ledford 1998; Parent 2002; Long and Shields 2005; Andrews, Bellmann, Schank, and Upward 2010), the question of whether employees benefit financially from profit sharing has never been satisfactorily resolved. While proponents argue that profit sharing increases employee earnings (Bell and Hanson 1987; Tyson 1996; Kruse, Freeman, and Blasi 2010), others contend that the effect of profit sharing on employee earnings will be neutral (Weitzman 1984), and still others argue that profit sharing can actually serve to reduce employee earnings (Katz and Meltz 1991). However, existing empirical evidence is insufficient to infer which of these outcomes generally prevails. Addressing this issue is important to scholars trying to unravel the effects of profit sharing, to managers and employees trying to decide whether to embrace profit sharing, and to public policy makers trying to assess whether public support for profit sharing is warranted.

Using panel data from a large sample of Canadian establishments, this paper examines whether employee earnings increase, decrease, or do not change in the period subsequent to adoption of profit sharing, relative to establishments that do not adopt profit sharing. Our research contributes to knowledge by utilizing longitudinal analysis to assess the effects of profit sharing adoption on employee earnings growth within a carefully constructed sample of Canadian establishments, and by assessing both cash real earnings growth and total real earnings growth, while controlling for a wide array of variables that may affect these results. Importantly, because the effects of profit sharing adoption may take considerable time to materialize, we examine both the three-year and the five-year period subsequent to profit sharing adoption. In so doing, we examine whether three firm-level variables may influence the relationship between profit sharing and employee earnings — employee participation in decision making, firm size, and pre-existing employee compensation level. 


\section{Theoretical and Empirical Background}

Why should employee profit sharing affect employee earnings? The answer seems obvious-if employees start receiving profit sharing payments in addition to their regular compensation, then their total earnings should increase. But note that this outcome is contingent on two key circumstances. Total employee earnings will increase only when (a) the employer is profitable subsequent to the adoption of profit sharing and actually pays a profit sharing bonus to its employees, and (b) this bonus exceeds any downward adjustments that may be made to other pay components subsequent to the adoption of profit sharing.

Regarding the first circumstance, proponents (Bell and Hanson 1987; Tyson 1996) argue that employee profit sharing is a practice that serves to increase company productivity, which in turn provides an avenue for increased employee earnings through profit sharing bonuses. Increased profits (deriving from productivity increases) would not only produce a larger profit sharing bonus than the employer would otherwise be able to provide, but would also provide the employer with a greater financial capacity on which to base increases to components of pay other than profit sharing. However, while the research evidence is quite clear that employee profit sharing does increase company productivity on average (Weitzman and Kruse 1990; Blasi, Freeman, Mackin and Kruse 2010), the evidence is equally clear that it does not do so in all cases (Kruse 1993; Magnan and St-Onge 2005; Robinson and Wilson 2006). But note that a causal connection between employee profit sharing and employer productivity is not a necessary condition for profit sharing to result in an increase in employee earnings. Provided that the employer is profitable subsequent to adoption of profit sharing, profit sharing could increase employee earnings — even absent any profitability-enhancing effect of profit sharing — through a redistribution of profit from capital to labor. 


\section{Motives for Profit Sharing}

Of course, paying a profit sharing bonus will increase net employee earnings only if employers refrain from making downward adjustments (in excess of the profit sharing bonus) to other pay components. Whether employers choose to make downward adjustments to other pay components likely depends on their motives for adopting profit sharing. Theory suggests three main sets of motives for adopting profit sharing, all aimed at enhancing firm performance, but operating through different processes.

The first set of motives is based on the "substitution argument” (Weitzman 1984; Kruse 1993). Under this argument, firms use profit sharing to substitute for fixed pay components (i.e. wages and benefits) to better align the firm's labor costs with fluctuations in its ability to pay. When the firm's financial capacity is high (i.e. in times of high profitability), employees receive a higher level of earnings; but when the firm's financial capacity declines, so do employee earnings, thus reducing labor costs. Absent a variable pay component (as provided by employee profit sharing), the main alternative for reducing labor costs is employee layoffs, which result in a variety of adjustment costs and risks loss of valuable human capital. Making labor costs more variable also reduces the firm's vulnerability to demand fluctuations and the attendant risks to firm survival. In his longitudinal studies of US firms, Kruse $(1993,1996)$ found that firms with higher financial variability (for which variable pay should be more attractive) were indeed somewhat more likely to adopt profit sharing. He also found greater employment stability in firms where profit sharing appeared to substitute for fixed pay.

Firms pursuing the substitution motive may effect this substitution gradually (through constraining future increases in fixed pay components) or more immediately. For example, a common use of employee profit sharing in Canada, and especially in the United States, is as a vehicle to accumulate retirement savings for employees (Kruse 1993; Long 2010). One 
possibility, then, is to discontinue an existing retirement savings plan that requires fixed commitments from the employer in favor of a retirement plan based on profit sharing. Another possibility is simply to cut wages in conjunction with the introduction of profit sharing, as was done by financially-troubled North American automakers during the 1980s (Katz and Meltz 1991). But regardless of how the substitution occurs, under the substitution argument we would not expect adoption of profit sharing to produce any long-term net gain in total employee earnings. However, a caveat to that comes from economic theory, which predicts that workers would demand higher total compensation than otherwise, in order to reimburse them for the risks inherent in variable pay. If so, this could actually result in workers under profit sharing receiving higher earnings, which would reduce the attractiveness of the substitution motive to employers.

In contrast, the second set of motives—the "human capital” argument—for profit sharing centers around using profit sharing as a vehicle explicitly intended to increase total employee earnings, with the object of enhancing attraction and retention of higher quality human capital. In this case, profit sharing may be regarded by employers as a less risky way to move to abovemarket "efficiency wages" than by increasing fixed wages and benefits. "Efficiency wages” may not only facilitate attraction and retention of higher quality labor, but might also enhance worker effort as workers may be more motivated to keep their above-market jobs. We also note that the "human capital” argument can be located within the broader "high road" approach to employee relations (Kochan, Katz and McKersie 1994) in which firms pay high wages and benefits, invest heavily in worker training and development, create broad and meaningful jobs, and allow a high degree of worker participation in decision making.

Alternatively, low-wage employers may use profit sharing to move closer to market pay rates. Either way, the employer has no intention of reducing other pay components, which would 
defeat this "human capital" purpose of the profit sharing plan. To effect this increase in total employee earnings, some employers may simply add profit sharing to their current compensation practices, while others may use profit sharing as a vehicle to deliver a new benefit to employees. For example, employers that do not currently have employee pension plans may introduce employee profit sharing as a vehicle for generating retirement savings (Kruse 1993; Tyson 1996). But regardless of the specific avenue selected, under the human capital argument we would expect adoption of profit sharing to increase total employee earnings over time.

The third set of motives—-the "worker behavior" argument—revolves around the explicit intention for profit sharing to serve as a productivity-enhancing vehicle, by enhancing employee motivation and cooperation on the job (Kruse 1996). In contrast to the "human capital" motive described above, the motive here is to increase firm performance not by attracting and retaining more highly qualified and productive employees, but by creating a work context in which existing employees are motivated to work more diligently and effectively towards organizational goals. Profit sharing is viewed as providing both the incentive and the reward for employees so doing (Strauss 1990). Under the “worker behavior” argument, increasing employee earnings is not the direct motive for profit sharing adoption, although that should occur if the profit sharing plan successfully engenders more productive worker behaviors.

Of course, these motives are not necessarily mutually exclusive. For example, an employer might intend for profit sharing to substitute for fixed wages while also hoping that profit sharing will motivate more productive employee behavior as employees start to bear more of the risk of poor firm performance (Robinson and Wilson 2006). Alternatively, an employer might intend for profit sharing to increase employee earnings and therefore attract better quality human capital, while also hoping that profit sharing will serve to motivate this high-quality human capital to maximize their productive behaviors. Even the substitution and the human 
capital motives are not totally incompatible, as it may be possible for employers to reduce fixed wages even while increasing total employee earnings, depending on how large the cuts in fixed wages are relative to the size of the profit sharing bonuses.

To predict the potential impact of employee profit sharing on employee earnings, understanding the motives of top management for introducing employee profit sharing would be helpful. However, only one study that attempts to directly tap the motives of top management for adopting employee profit sharing could be found. Long (1997) conducted telephone interviews with chief executive officers (CEOs) of Canadian firms that had recently implemented employee profit sharing. Using an open-ended question, he found that the most frequently cited motives for adopting profit sharing could be clustered into two main groups, corresponding to the "worker behavior" and "human capital” motives discussed earlier. The first group of motives centered around improving company performance, through “improving employee motivation," "promoting teamwork," or "helping employees better understand the business." The second set of motives centered around providing better rewards to employees, with profit sharing seen as “improving the compensation package,” "rewarding loyal employees," "retaining employees,” and "building employee commitment."

Interestingly, no Canadian CEO mentioned any motive that implied making pay more variable by reducing the fixed portion of pay. However, a survey of managers (not necessarily CEOs) employed at US firms with employee profit sharing that queried whether profit sharing was best at "raising productivity," “increasing loyalty”, or “linking labor costs to the firm’s economic conditions" found that the answer most frequently selected was "linking labor costs," followed by "increasing loyalty," which suggests support for the "substitution" and "human capital” motives, respectively (Mitchell and Broderick 1991). But given that these respondents were not necessarily involved in the decision to adopt profit sharing, it is possible that their 
responses do not necessarily reflect the original motives for adoption of profit sharing, but more the respondent perceptions of the results of profit sharing.

As a final comment here, we note that the national context could have an impact on both motives and outcomes of profit sharing. A variety of writers (Belanger, Lapointe, and Levesque 2002; Godard 2004; Kalmi and Kauhanen 2008) have argued that employees in countries that could be characterized as "coordinated market economies" (with strong unions, statutory employee representation and job protection) such as Germany, Sweden, and Finland, would see more employee benefit from "workplace innovations" than in "liberal economies," such as the United States, the United Kingdom, and Canada, because there is a strong context in coordinated economies to translate productivity gains into employee earnings. Relating this to profit sharing in Canada, this argument would seem to apply to the "worker behavior" and "substitution" models for implementation. In the first case, the profit sharing formula could be devised in such a way that workers see relatively little gain from increased productivity, and in the second case the benefit to the firm is seen as replacing fixed pay with at-risk pay, thus not benefiting workers.

\section{Empirical Evidence on Profit Sharing and Employee Earnings}

Turning to the empirical evidence on the effects of profit sharing on employee earnings, while there has been a considerable amount of research conducted on this question, most evidence is cross-sectional in nature, precluding causal inferences. For example, Mitchell, Lewin, and Lawler (1990) used 1974 survey data from the United States Bureau of Labor Statistics, and found that both employee hourly wages and total compensation were higher in firms with profit sharing. But in further research reported in that same paper, they examined union contracts during the 1981-1988 period, and found that 36\% of union contracts containing profit sharing provisions also included first year wage reductions, compared to only $14 \%$ of contracts that did not contain profit sharing. Using a similar time period (1978-1987), Bell and Neumark (1993) 
found that, among unionized manufacturing firms in the United States, those with profit sharing showed a lower growth in labor costs than firms without profit sharing (implying that profit sharing served to constrain employee earnings).

A survey by the US Chamber of Commerce (1989) conducted in 1989 found that, in the manufacturing sector, fixed compensation was lower in profit sharing firms than those without profit sharing, but the opposite was true among nonmanufacturing firms. Kim (1998) used a US data base collected in 1986 to conclude that profit sharing had increased labor costs in US firms, and, by implication, employee earnings. In line with this, a study by Handel and Gittleman (2004), based on 1995 data from US business establishments, found profit sharing to be significantly positively related to employee earnings, as did Azfar and Danninger (2001) based on 1988-1994 data from young, white US males in non-union firms. Based on US data, Kruse, Freeman, and Blasi (2010) concluded that profit sharing had a positive effect on employee earnings. However, a study by Black, Lynch, and Krivelyova (2004), which utilized 1996 data from US firms, found no relationship.

In European research, Estrin and Wilson (1989) found that, among British engineering and metalworking firms during the period 1978-1982, fixed pay was higher in firms with profit sharing than those firms without profit sharing. Wadhwani and Wall (1990) also found in their sample of British manufacturing firms that profit sharing was associated with higher total employee compensation. Hart and Hubler (1991) examined a survey of German workers conducted in 1984-1985, and found that profit sharing was associated with higher individual wages, and found no support for the substitution argument. However, a British study (Forth and Millward 2004), based on 1998 data, found no relationship between "financial participation" (which co-mingled profit sharing and employee stock plans) and employee hourly earnings, and a study by McNabb and Whitfield (2007) based on the same data set found no relationship 
between presence of employee profit sharing and employee earnings.

However, to adequately address the question of whether profit sharing affects employee earnings, longitudinal research is needed, and just three such studies could be found. Parent (2002) used data from the US National Longitudinal Survey of Youth collected during the 1990s to examine individual employee earnings before and after employees started receiving profit sharing payments and found interesting results—profit sharing apparently increased the earnings of male employees, but had no impact on the earnings of female employees. Kruse (1993: 117) examined data from US public corporations during the 1975-1990 period and concluded that there was "very little difference in average compensation growth" between those firms that had or had not adopted profit sharing. He also concluded that there was some evidence for a substitution effect, as a slight increase in total compensation among profit sharing firms (relative to non-profit sharing firms) was less than the amount of the profit sharing bonuses. But as he notes, the sample on which he bases this conclusion is small, numbering just 30 companies.

Finally, in their German study, Andrews, Bellmann, Schank, and Upward (2010) examined the effects of profit sharing adoption during 2001-2005 on employee earnings in the two years subsequent to that period. They found that employees in firms with profit sharing plans did earn substantially more than other employees (about 25\% more), but they also found that employees in profit sharing adopters also earned more (about 27\%) prior to the adoption of profit sharing. After adjusting for this, and other variables, they concluded that the effect of profit sharing on employee earnings was in the $2.5-4.0 \%$ range, over the two year study period. 


\section{Possible Conditions Affecting the Relationship between Profit Sharing and Employee Earnings}

Besides the question of whether profit sharing affects employee earnings, we also examine several conditions that may influence this relationship. Specifically, does employee participation in decision-making, establishment size, or the pre-existing compensation level of employees affect the relationship between employee profit sharing and employee earnings growth subsequent to adoption of profit sharing?

If profit sharing is to increase total employee earnings, it is more likely to do so when profit sharing serves to increase the total financial resources available to the firm. Although the precise conditions under which profit sharing is most likely to enhance the financial performance of the firm are not well understood, one of these possible conditions is scope for employee participation in decision making. Numerous commentators (Bell and Hanson 1987; Kandel and Lazear 1992; Strauss 1990) argue that profit sharing will be more effective in improving organizational performance when accompanied by participatory practices. Consistent with the “worker behavior” model, proponents argue that participatory practices serve as key channels through which employees can operationalize the interest in workplace performance that has been generated by the financial incentive (Levine and Tyson 1990). This argument is also consistent with the "high-involvement," "high-commitment," or "high-performance” models of strategic human resource management, which posit that it is the interaction between a variety of complementary human resources practices which produces significant increases in company performance (Lawler 1986, 1992; Delery and Doty 1996; Pil and MacDuffie 1996; Allen and Wright 2007). If there is a significant interaction between profit sharing and employee participation, the ensuing higher company performance in profit sharing firms that also have participatory practices should translate into higher employee earnings, by increasing the size of 
the profit sharing bonuses, or by increasing the firm's capacity for higher fixed pay, or both.

Therefore, if the "worker behavior" path to firm performance is an important one, we should see a positive interaction between adoption of profit sharing and employee participation in predicting employee earnings growth over time, and there is in fact some empirical evidence that supports this argument, as McNabb and Whitfield (2007) found a significant positive interaction between profit sharing and employee participation (in the form of joint consultative schemes) on employee earnings in Britain. On the other hand, Handel and Gittleman (2004:88) found that “...the addition of most practices does not raise establishment wages above the level associated with profit sharing alone...”

While no other studies examining a possible interaction effect for profit sharing, participation, and employee earnings could be found, several studies did examine a possible interaction for profit sharing, participation, and firm performance. While firm performance is not an identical variable to employee earnings, it seems plausible that practices that improve firm profitability may also eventually be reflected in employee earnings through higher profit sharing payments. Kim (1998) found in his US sample that profit sharing increased firm profitability when combined with employee involvement programs, but not otherwise. But we note that the evidence on a possible profit sharing/participation interaction is not consistent, as Robinson and Wilson (2006) found no significant interaction between profit sharing and employee “participation in control” in predicting firm performance in Britain, nor did Kalmi, Pendleton and Poutsma (2005) in their study of four European countries.

A second factor that may influence the relationship between employee profit sharing and employee earnings is company size. If company size affects the success of profit sharing, then this may also affect the employee earnings produced by profit sharing. Traditionally, a larger company size is seen to work against the success of profit sharing, based on what economists 
refer to as the "1/n" or "free-rider" problem (Olson 1971; Jensen and Meckling 1976). If an individual employee increases effort and productivity, that individual receives only a small portion of the productivity gain, having to share it with all others included in the profit sharing system (“n”). Even if an individual does not change his or her effort, he or she can still gain from the increased effort of others, and thus become a "free rider." The magnitude of this problem is thought to increase as " $n$ " increases, suggesting that larger firms will benefit less from profit sharing than smaller firms. If in fact large firms do benefit less from profit sharing (the empirical evidence is equivocal on this point) then employees in large firms should benefit less under profit sharing than those is smaller firms. This concern is greatest for those who see "worker behavior” as the primary link between profit sharing and improved organizational performance, and not a big concern to those who see other avenues (i.e. "substitution” or "human capital”) as the key links between profit sharing and firm performance. A negative interaction between firm size and employee earnings growth would be consistent with the free rider argument and the worker behavior model of profit sharing effects.

A third factor that may condition the relationship between profit sharing and employee earnings is the relative value of the human capital employed within the firm, as proxied by whether the firm compensates its employees above the market average for its industry. Presumably, firms pay above-market wages (“efficiency wages”) in order to attract and retain a higher quality of human capital. Hart and Hubler (1991) point out that under rent-sharing theory, workers with relatively high levels of wage compensation are more likely to be included in profit sharing (because these employees presumably can play a greater role in creating these "rents" than other employees), as Long and Fang (2007) have found in their Canadian sample. Because of the value added by these employees, and their relative scarcity, it seems unlikely that firms with a high investment in human capital would use profit sharing for any purpose other than 
sharing rents, thus raising the total earnings of their employees. Overall, to this extent that this “human capital argument” holds sway, we would expect a positive interaction between adoption of profit sharing and high wages in predicting employee earnings growth over time.

\section{Methodology}

\section{Data and Research Design}

In conducting this research, we utilize a longitudinal panel of data, based on the Workplace and Employee Surveys (WES) conducted by Statistics Canada from 1999 (the first year in which the WES was conducted) to 2006 (the last year in which the WES was conducted). These surveys are designed to be representative of the total population of "workplaces" in Canada, but exclude business locations in the sparsely populated Yukon, Nunavut and Northwest Territories, as well as those in agriculture, fishing, road, bridge and highway maintenance, government services and religious organizations. The WES then follows the same workplaces over time, although replacement is made in every third year for workplaces that drop out of the survey. As utilized by Statistics Canada, a "workplace” is a business unit located at a single geographic location, and is analogous to the term "establishment" as frequently used in survey research. In this paper, we will generally use the more commonly understood term "establishment" to denote the unit of analysis. Our sample is limited to for-profit organizations only.

The sample frame for the WES was generated from the Statistics Canada Business Register, which is a list of all businesses in Canada, updated monthly. Prior to sample selection, the business locations on the frame were stratified by industry, region, and size (based on estimated employment), and the sample was then selected using a Neyman allocation (Statistics

Canada, 2004). The response rates for our selected years (1999, 2001, 2004, and 2006) of 
workplace surveys are stated by Statistics Canada as 95.2\%, 85.9\%, 81.7\%, and $74.9 \%$ respectively, with most of the "non-responders" comprising owner-operators with no paid employees (Statistics Canada 2006). Given the breadth and sensitivity of the information collected, these are rather remarkable response rates, no doubt facilitated by the facts that cooperation with Statistics Canada is obligatory and that extensive legal protections ensure confidentiality of responses. ${ }^{1}$

Data were collected through computer-aided telephone interviews with senior management officials at each workplace, conducted by trained interviewers based in Statistics Canada's regional offices. Each workplace was first sent a copy of the survey, with instructions to regard the survey as "as a working tool to inform you ahead of time of the questions being asked and to help you in preparing your answers.” As the survey is lengthy, and includes many questions requiring reference to company records, the intent was to allow respondents time to locate this information before being interviewed. The instructions emphasized that the survey forms are not to be returned by mail, but that the information is to be provided directly to the interviewer. The intent here was to provide the opportunity for the interviewer to clarify questions and answers, and then to follow up if necessary.

After each survey, before any data were made available for research purposes, Statistics Canada spent more than two years conducting various procedures to ensure a clean data set. During data collection, the computer-aided interview format provided various checks to reduce the possibility of input errors or incorrectly recorded values. Following data collection, extended input editing was applied, followed by extensive data analysis and ratio editing to determine outlying observations based on robust outlier detection programs (Statistics Canada 2004).

\footnotetext{
${ }^{1}$ It can be observed that the response rate was dropping during the survey period, but we don't consider this problematic, since most surveys would be delighted to report a 75\% response rate. By 2006 many of the workplaces will have been asked to respond to the same survey for seven consecutive years, so it is likely that some survey fatigue was setting in.
} 
We constructed two panels of longitudinal data-one based on a three-year period subsequent to profit sharing adoption, and the second based on a five-year period subsequent to profit sharing adoption. The three-year panel was constructed by first taking the 1999 WES sample and eliminating all workplaces with less than ten employees, those that are not for-profit enterprises, those that reported having profit sharing in 1999, and those that were not also included in the 2001 and 2004 surveys. We also eliminated workplaces that adopted profit sharing during the period after 2001, so we would know that all adoptions occurred during the 1999-2001 window. We used a similar method to create our five-year panel, this time using the 2001-2006 period. This resulted in 1,717 workplaces in our three-year panel, and 1,566 in our five-year panel. We based our independent variable ("Profit Sharing Adoption”) on whether the workplace reported having employee profit sharing in the 2001 survey, with " 1 ” indicating that the workplace had adopted profit sharing, and " 0 " indicating the workplace continued to not have employee profit sharing.

The rationale for this approach is that we wished to identify recent adopters of profit sharing (i.e. those that adopted between the 1999 and 2001 surveys), and then follow the growth of employee earnings during the three-year period 2001-2004 and during the five-year period 2001-2006. In this way, we have pre-existing data for both the workplaces that did and those that did not adopt profit sharing, and can compare earnings growth in the two groups, while incorporating a large array of control variables (as measured in 2001). In choosing an appropriate time period to assess the effects of implementation, we wanted to allow enough time for the possible effects to materialize, but not so much time that too many exogenous events would occur. We note that, when assessing the effects of participatory practices on employee earnings, Osterman (2000) chose a five-year period, and this seemed reasonable to us as our outer limit.

The average workplace size (number of employees) is 51, and 31.9 percent of workplaces 
are unionized. The average union density is 22.3 percent. The distribution of workplaces by industry is: resources (1.4\%), labor-intensive tertiary manufacturing (5.8\%), primary product manufacturing (3.1\%), secondary product manufacturing (5.8\%), capital intensive tertiary manufacturing (6.3\%), construction $\quad(6.1 \%)$, transportation/wholesaling $\quad(14.3 \%)$, communication/utilities (3.3\%), retailing/consumer services (21.9\%), finance/insurance (7.5\%), real estate (1.6\%), business services (15.2\%), education and health services (5.3\%), and information/cultural services (2.4\%).

\section{Variable Measures}

An establishment was deemed to have adopted employee profit sharing if respondents to the 2001 WES responded "yes” to the following question:

“Does your compensation system include ... [a] profit sharing plan? Profitsharing plan is any plan in which employees receive a share of the profits from the workplace.”

Any plans that applied only to managers were not deemed to be "employee profit sharing plans," and these cases were eliminated from the panel. All remaining cases were designated "0" (no profit sharing adoption) or " 1 ” (profit sharing adoption). Of the 1,717 establishments that did not have employee profit sharing in 1999, 247 (14.4\%) had adopted it by $2001 .^{2}$

Two measures of employee earnings growth are utilized. In so doing, we use an approach similar to that used by Kruse (1993) to control for industry differences. Growth in cash employee

\footnotetext{
${ }^{2}$ One potential concern with measurement of the independent variable, profit sharing adoption, is that the different surveys may be answered by different people over time, who construe profit sharing differently — with some respondents failing to report profit sharing when it does exist, and others reporting it when it doesn't truly exist. While this concern is always present in panel data, we feel that the definition of profit sharing in the survey is quite clear, and since data were collected through telephone interviews, it was possible for the respondent to clarify the meaning of profit sharing. We also eliminated cases where profit sharing was reported in 2001, but seemed to disappear in subsequent surveys. So, a firm was counted as having profit sharing only if it reported profit sharing in 2001, 2004, and 2006. We also eliminated firms that did not report profit sharing in 2001, but did report it in one of the subsequent surveys. The main reason for eliminating these cases is that we wanted to a have a "clean" sample of establishments that either did or did not have profit sharing for the entire period 2001-2006., but this policy may also have served to reduce response inconsistency.
} 
earnings was calculated by first taking the total gross payroll (including regular wages, commissions, overtime pay, piecework payments, and special payments) during the most recent fiscal year prior to data collection in 2001, and dividing this sum by the full-time equivalent number of employees at the establishment ${ }^{3}$. We derived a "Cash Real Earnings Growth" variable by subtracting the mean real earnings per employee (based on total payroll) at each establishment in 2001 from the mean employee earnings (CPI-adjusted) at that establishment in 2004, and dividing by the mean 2001 cash earnings at that establishment. (We used the same process for the five-year panel, using 2006 as the end year.)

However, merely using “cash real earnings growth” as the dependent variable may not portray the entire earnings picture. For example, some employers may consider profit sharing payments as "benefits" rather than cash earnings. This may be particularly true in cases where profit sharing payments are deferred, and are used as part of a retirement plan. Therefore, we also used a second measure of employee earnings growth—“Total Real Earnings Growth.” This measure was calculated in the same way as "Cash Real Earnings Growth,” except that it also included the cash value of non-wage benefits, such as the employer's contribution to pension plans and other employee benefits. A key advantage of this measure of earnings growth is that it also incorporates any changes in the value of non-wage benefits subsequent to adoption of profit sharing. It is conceivable, for instance, that an employer may reduce non-wage benefits (e.g. pension plans) in concert with or subsequent to the adoption of profit sharing.

One disadvantage of this method is that establishments with higher employee earnings in 2001 will tend to show lower earnings growth than establishments with lower employee earnings,

\footnotetext{
${ }^{3}$ Because establishments use a widely varying mix of full-time and part-time employees, we calculated "full-time equivalent employment” by multiplying part-time employees by .42 and adding this product to the number of fulltime employees reported at each establishment. We derived this factor from examining Statistics Canada data (Usalcas 2008). We found that in 2001, the average part-time worker in Canada worked approximately .416 the hours of a full-time employee, and by 2006 the ratio was .421. We rounded to .42, which we used as our conversion factor to translate part-time employees to full-time equivalents.
} 
simply because of the higher base. To deal with this, we include the 2001 mean employee earnings at each establishment as a control variable in all of our regression equations. ${ }^{4}$ We examined the impact of not including this variable in our regression equations, and found, as we expected, a reduction in the magnitude of the resulting regression coefficients.

To assess employee participation, we utilize a “participatory practices" index. Respondents were asked which (if any) of the following practices are currently in place, on a formal basis, for nonmanagerial employees: (a) suggestion systems, (b) problem solving teams, (c) joint labor-management committees, (d) information sharing programs, (e) flexible job design, and (f) self-directed work groups. The participatory practices score for each establishment is the total number of these practices in place, and thus varies from " 0 " to "6". This type of method has been commonly used in attempting to ascertain the extent to which firms practice employee participation (Pil and MacDuffie 1996; Zatzick and Iverson 2006). Because this variable measure is an index, and not a scale, reporting of a value for Cronbach's alpha is not appropriate (Delery, 1998).

To control for industry sector, thirteen dummy variables are created, representing all of the sectors discussed earlier in this section, with the exception of retailing, which serves as the omitted (comparison) variable for analytical purposes. A further set of controls is used to control for the possible effect of performance pay other than profit sharing. For example, individual incentives have long been positively associated with employee earnings (Lazear 2000; Mitchell, Lewin, and Lawler 1990; Parent 2002), and recent Canadian research has shown that presence of numerous types of performance pay are positively associated with presence of profit sharing (Long 2002). Therefore, we use dummy variables to control for the presence of individual

\footnotetext{
${ }^{4}$ One additional benefit of controlling for earnings 2001 is that it makes the profit sharing and non-profit sharing groups statistically more similar.
} 
incentives, merit pay, gain sharing, and employee stock plans. We also control for union density (the proportion of total employees at a given establishment covered by a collective bargaining agreement) and establishment size (the total number of full-time equivalent employees at a given establishment). All of these variables are based on how they stood at 2001, by which time all the establishments in our sample which were to adopt profit sharing had done so.

These controls are included in all multivariate analysis. Data analysis was carried out using OLS multiple regression ${ }^{5}$, with each workplace weighted to represent its proportion in the general population. Statistics Canada strongly encourages the use of establishment weights so that any results are broadly representative of the Canadian population of establishments. Because larger establishments tend to over-represented in our sample, the effect of weighting is to apply higher weights to smaller establishments. We did try the analysis using unweighted data, and found somewhat stronger effects, but we adopted the more conservative approach recommended by Statistics Canada.

Besides testing for main effects, we conducted a second set of estimations testing for interaction effects of profit-sharing adoption with employee participation, firm size, and preexisting compensation level, as they stood in 2001. Interaction terms were constructed by multiplying profit sharing adoption by the participation index, profit sharing adoption by establishment size, and profit sharing adoption by 2001 employee earnings. All continuous variables contained in the interaction terms were mean-centered before inclusion in the regression equations (Cohen et al. 2002).

\footnotetext{
${ }^{5}$ We considered using a fixed effects model for our regression analysis, but because of our research design and relatively short panels of data that we use, we believe that OLS may be the more appropriate estimator. We believe that use of a fixed effects model under short data panels could generate imprecise estimates for our large number of establishment dummy variables, which could, in turn, affect the precision of our other coefficient estimates.
} 


\section{Results and Discussion}

Table 1 shows the means, standard deviations, and bivariate correlations for the sample. As can be seen, numerous variables are significantly related to profit sharing adoption. Profit sharing adopters are more likely to have all four types of performance pay plans-merit pay, individual incentives, gain sharing, and employee stock plans-than establishments that did not adopt profit sharing. Establishments with more participatory practices are significantly more likely to adopt profit sharing, while establishments with higher union density are significantly less likely to adopt profit sharing. This confirms the importance of controlling for these variables in our multiple regression analyses.

Insert Table 1 about here

Profit sharing adopters also show significantly higher employee earnings in 2001—both cash earnings and total earnings — than establishments that did not adopt profit sharing. That establishments which adopt profit sharing have higher employee earnings prior to profit sharing adoption highlights the dangers of drawing conclusions about the effects of profit sharing from cross-sectional data, and the need for the use of longitudinal data, such as the data set used in our study.

Table 2 shows the multiple regression results, for both real cash employee earnings growth and real total employee earnings growth. As can be seen, profit sharing adoption is not significantly related to real employee earnings growth over the three-year period subsequent to adoption of profit sharing, regardless of whether the measure of real earnings growth is cash compensation or total compensation. The unstandardized regression coefficients are positive, but do not reach statistical significance. Thus, at three years after adoption, profit sharing appears to 
have neither decreased employee earnings, as critics would fear, nor have significantly increased employee earnings, as advocates would expect.

Insert Table 2 about here

However, the picture changes when examining the results over a five-year period, as Table 2 also shows. Over the period 2001-2006 real employee earnings growth—whether cash earnings or total earnings - is significantly higher for establishments that adopted employee profit sharing than establishments that did not do so. Over the five-year period, real employee earnings in profit sharing firms increased by about 15 percentage points more than in firms not adopting profit sharing. Besides being statistically significant, this magnitude is also practically significant, given that the five-year real earnings growth for non-adopters is about $10-11 \%$. In passing, though, we should note that the annualized difference in earnings growth between profit sharing adopters and non-adopters over the five-year period (at about 3\% per annum) is very similar to the annualized difference in earnings growth over the three-year period (at about 2.5\% per annum). It seems that the non-significant results for the three-year period may simply reflect an insufficient period for the differences in earnings between profit sharing adopters and nonadopters to significantly manifest themselves.

In order to more fully understand the relationship between profit sharing adoption and employee earnings, we constructed Figure 1. This figure shows the average total employee earnings (in nominal dollars) annually from 1999 to 2006 for establishments that did or did not adopt profit sharing. Several things are notable. First, in 1999, when none of the establishments in our sample had profit sharing, establishments that did go on to adopt profit sharing showed average total employee earnings that were about $14.6 \%$ higher than establishments that did not 
subsequently adopt profit sharing. Interestingly, by 2001, when all of the establishments which were to adopt profit sharing had done so, that gap had shrunk to about 9.0\%. During 1999 to 2001 employee earnings had increased in both adopters and non-adopters, but more so in nonadopters.

Insert Figure 1 About Here

Perhaps even more interestingly, between 2001 and 2002, employee earnings in adopters actually declined, while employee earnings in non-adopters increased slightly, resulting in a very small difference in employee earnings between the two sets of establishments in 2002. However, by 2004 , employee earnings in adopters were about $12.0 \%$ higher than in non-adopters, and by 2006 about 17.8\% higher in adopters than in non-adopters (thus exceeding the 14.6\% gap in 1999). This pattern of results suggests at least three things. First, that employee earnings became much more variable in establishments that adopted profit sharing, relative to non-adopters, is in congruence with one of the key characteristics claimed for this form of "variable pay." This is probably not surprising, since the compensation level of the profit-sharing firms should be more sensitive to profits, thus business cycles. This is consistent with the fact that a short-lived economic recession occurred during the 2000-2001 period. Second, this pattern suggests that many firms may have substituted profit sharing for some portion of fixed pay at or shortly after profit sharing adoption. One plausible interpretation is that a reduction in fixed pay outweighed any gains from profit sharing in the first year of adoption, but that gains accruing from profit sharing bonuses outweighed any losses in fixed pay over the longer run, and certainly by four or five years after adoption. This interpretation is very consistent with the regression coefficients for the three-year period subsequent to adoption (positive, but not significant) compared to the 
five-year regression coefficients (positive and significant). Third, employees may not immediately benefit financially from profit sharing, but appear to do so over the longer term (4-5 years). This is because the implementation cost of the profit-sharing plans comes in more immediately, thus limiting the employer's ability to pay (at least in the short-run), while the profit-sharing takes time to come into effect and to produce effects.

In this respect, our results might be seen as consistent with the worker behavior model. The fact that it takes several years for significant differences in real earnings growth between adopters and non-adopters to materialize may suggest a chain of events in which adoption of profit sharing gradually causes worker behavior to become more productive, which subsequently manifests itself in increased firm-level profitability, which eventually is reflected in larger profit sharing bonuses and therefore increased employee earnings, cumulatively sufficient to outweigh any earnings losses due to a substitution effect.

Still another plausible argument is that firms are simply using profit sharing as mechanism to increase employee earnings, thus making it more likely than they can preserve or enhance their human capital. The finding that establishments that already pay above industry averages (and thus presumably have a more valuable stock of human capital) are more likely to introduce profit sharing than firms that do not pay above market averages (Long and Fang 2007) fits with this argument. Enhanced ability to retain and attract higher quality human capital may enhance competitive advantage among these firms, increasing firm performance and also employee earnings through higher firm profitability. As under the worker behaviour model, this increase in firm performance will take some time to percolate into employee earnings.

One way of examining the plausibility of these differing explanations of why profit sharing may cause higher employee earnings is through interaction analysis. For example, employee participation in decision making within the establishment is often seen as a 
complement to profit sharing, in that employee participation can provide an avenue through which the greater employee interest in company productivity engendered by profit sharing can be channeled into actual productivity improvements (Handel and Levine 2004; Jones, Kalmi, and Kauhanen 2010). If so, firms adopting profit sharing that also have extensive participatory practices should benefit more from profit sharing than other adopters of profit sharing, and this should be reflected in stronger employee earnings growth among profit sharing adopters with participatory practices. However, results of interaction analysis (displayed in Table 3) showed extremely low interaction coefficients for profit sharing adoption and participatory practices, which did not approach statistical significance. If the worker behavior argument applies, one would have expected to see a significant positive interaction. ${ }^{6}$

Insert Table 3 About Here

Another way of examining the plausibility of the differing explanations is to examine whether employee earnings growth is affected by the size of the firm in which profit sharing is implemented. One of the motivational bases underpinning the worker behavior argument is that performance-contingent rewards provided by profit sharing should increase employee motivation to increase job performance. This should be more noticeable in smaller establishments, where there is a clearer "line of sight" between individual employee performance and the rewards they receive through profit sharing. However, interaction analysis showed that employee earnings

\footnotetext{
${ }^{6}$ We note that this result also shows no support for the "complementarity" theory of profit sharing and employee participation that is often discussed in the literature (Handel and Levine 2004) and for which some empirical support has been found (eg. Jones, Kalmi, and Kauhanen 2010). But we also note that while an interaction effect between profit sharing and worker participation on employee earnings would have provided strong support for the "worker behavior" model, lack of such an interaction does not necessarily invalidate the worker behavior model. It is still possible that profit sharing may enhance worker behavior in a variety of ways, regardless of whether or not worker participation is in place.
} 
growth was not affected by establishment size of profit sharing adopters, a finding that does not support the worker behaviour argument.

To examine the plausibility of the human capital argument, we interacted profit sharing adoption with 2001 employee earnings to predict employee earnings growth subsequent to profit sharing adoption. If firms that pay higher wages prior to adoption of profit sharing show higher growth in employee earnings subsequent to profit sharing adoption compared to firms that did not adopt profit sharing, this would suggest that firms adopting profit sharing are motivated by human capital concerns, and are using profit sharing to increase the earnings of their employees. In fact, Table 3 shows that the interaction coefficients are positive and statistically significant for both dependent variables, for the three-year period. However, the coefficients lose statistical significance over the five-year span. We then compared the exact coefficients for cash earnings growth for the three-year term compared to the five-year term for cash earnings growth (.00494; .00416) and for total earnings growth (.00283; .00328) and we found the coefficients quite similar. It is possible that the somewhat smaller size of the five-year sample may have accounted for the loss in statistical significance.

Overall, this result suggests that the positive main effect of profit sharing adoption may been driven disproportionately by the high-wage adopters of profit sharing, at least in the first three years. We note that this is consistent with both the human capital argument and the "high road” argument (Kochan, Katz and McKersie 1994). Indeed, results indicating that profit sharing adopters also are more likely to have employee participation in decision making and other types of financial incentive are consistent with this interpretation.

In order to examine this finding more closely, we constructed Figure 2, which visually displays the relationships between profit sharing adoption and average annual total employee earnings during the period 1999 to 2006, for both high-paying and low-paying establishments. In 
doing so, we split our sample at the median of average total employee earnings in 2001, by which time all establishments in our "profit sharing” group had actually adopted profit sharing.

Insert Figure 2 About Here

Figure 2 shows very different (and quite complicated) patterns of results for the "highearnings" subgroup compared to the "low-earning” subgroup. Of course, we would expect to see differences, since we have seen a significant interaction effect between profit sharing and employee earnings, but the interaction graphs help us understand the nature of the differences. Taking the "high-earning” group of establishments, it can be seen that, for both adopters and non-adopters, employee earnings were increasing sharply during 1999-2001, but then drop sharply during 2001-2002. Establishments that would subsequently adopt profit sharing paid about $13.5 \%$ more than non-adopters in 1999 and the earnings gap was very similar (at 12.5\%) in 2001. However, during 2001-2002, employee earnings plunged in both adopters and nonadopters, but more so in adopters, with the earnings gap between adopters and non-adopters narrowing to about $7.0 \%$ in 2002. After that, during 2002-2003 employee earnings in adopters increased and then more or less held steady, albeit dipping slightly in 2006. In contrast, earnings in non-adopters continued to decline until 2004, at which time there was a $16.7 \%$ gap between adopters and non-adopters. While earnings among non-adopters recovered a bit after this, the gap between adopters and non-adopters in 2006 was about 12.0\%, close to what it was in 2001, and not far off from what it was in 1999, prior to adoption of profit sharing.

As mentioned, the pattern in the "low-earnings" group is very different from that in the “high-earnings” group. In the “low-earnings” group, employee earnings plunged between 1999 and 2001, with earnings in future adopters dropping considerably more than in non-adopters. In 
fact, an $11.3 \%$ earnings advantage among future adopters relative to non-adopters in 1999 had become a 3.7\% disadvantage by 2001. Earnings rose in both adopters and non-adopters subsequent to 2001, and this gap was subsequently closed by 2003. During 2003-2004, employee earnings in profit sharing adopters tracked earnings in non-adopters, but substantially outpaced non-adopters during 2004-2005, ending up with a 13.7\% advantage by 2006.

Taking these results together, it can be seen that during the period 2001-2004 profit sharing apparently benefited employees in high-earnings establishments by reducing the degree of decline in earnings that they might have otherwise suffered. Then, during 2004-2006, profit sharing served to preserve their pay advantage in the face of increasing pay among non-adopters. Profit sharing could therefore be seen as having the effect of helping establishments with high human capital maintain their earnings advantage over their competitors, thus helping to preserve their human capital, while also reducing risk to the employer by making employee pay more responsive to the economic circumstances of the establishment.

In contrast, during 2001-2004, profit sharing apparently brought little or no advantage to employees in the "low-earnings" group, with employers apparently using profit sharing as a vehicle to simply reduce the fixed portion of employee earnings. Indeed, three years after profit sharing adoption, employees in "low-earnings" adopters showed virtually identical employee earnings to non-adopters, despite presumably now having a higher proportion of their pay "at risk” compared to non-adopters. Moreover, employees in "low-earnings” profit sharing adopters had also seen the $11.3 \%$ earnings advantage they had enjoyed in 1999 , prior to profit sharing adoption, wither away to nothing in 2004. Thus, it appears that profit sharing was beneficial to employees in "high-earnings" establishments but not in "low-earnings" establishments during the three years following profit sharing adoption. However, a caveat needs to apply to these conclusions for employees in "low-earnings" adopters--when viewed through the prism of a five- 
year period subsequent to profit sharing adoption, the earnings advantage of employees in adopters over non-adopters (13.7\%) was actually greater than that in 1999 (11.3\%) prior to profit sharing adoption. Thus, the "payoff" to profit sharing took much longer to materialize for employees in "low-earnings" establishments than in "high-earnings" establishments, but did eventually materialize. ${ }^{7}$

Overall, these results are consistent with the notion that establishments with a high investment in human capital will use profit sharing as a means to "share economic rent" and thus enhance the financial rewards to their employees, in line with the "human capital" motive for profit sharing adoption. Increased attraction and retention of high quality human capital may translate into productivity improvements over time that, in turn, make it more feasible for firms to offer above-market compensation, in the form of profit sharing bonuses. This may in fact play into a "high road" employment relations strategy that may be practiced by some of these firms.

Our findings suggest that profit sharing may be a particularly good fit for high-wage firms, given their need to protect and leverage their high investment in human capital, while minimizing their vulnerability to demand fluctuations. Moreover, employees in high-wage firms are likely to be more comfortable with the compensation risk engendered by profit sharing, since their total earnings are higher than in other firms, and they are more able to afford take some risk with a portion of their earnings than are employees who are less financially privileged. They may well buy into the notion that profit sharing provides their employer with the compensation flexibility to allow the employer to continue to offer above-market total compensation. That profit sharing may be an especially good fit for high-wage firms is supported by research indicating that the most important determinant of profit sharing adoption in Canadian firms is a

\footnotetext{
${ }^{7}$ One potentially relevant observation is that, during 2001-2004, overall earnings of employees in high and low wage establishments showed some convergence, as employee earnings in high-wage establishments tended to drop, and employee earnings in low wage establishments tended to increase. However, during 2002-2004, earnings in high-wage adopters partially resisted the tendency to converge with low-wage establishments.
} 
high-wage policy prior to adoption of profit sharing (Long and Fang 2007).

One finding of some interest is the eventual uptick in employee earnings in low-wage establishments. In these establishments, the human capital argument does not seem to apply, as establishments appeared to use profit sharing to substitute for fixed pay, and many may be attempting to apply a "low road" employee relations strategy. Even with profit sharing, lowwage adopters showed lower total employee earnings one year after adoption (2002) than did low-wage non-adopters, and virtually identical earnings to non-adopters in 2003 and 2004. For employees in low-wage establishments, all that profit sharing apparently accomplished for them (in the first three years, at least) was to put a higher proportion of their pay at risk with no offsetting financial gain. This may have made it more difficult for these employers to retain their employees, who may have viewed profit sharing as simply another means to exploit them. It may be that low-wage adopters eventually found that they needed to be more competitive with the fixed component of their pay in order to attract and retain workers as economic conditions improved during the mid-part of the decade, thus accounting for the 2005-2006 uptick in employee earnings in these firms. An alternative explanation is that benefits of pay flexibility provided by the profit-sharing plans are greater to the low-wage establishments given their relatively fewer resources available, which can eventually be translated into the financial gains by the workers.

As with all empirical studies, our study has both strengths and limitations. Strengths include use of a data set that embodies a large-scale sample, a very high response rate, and is carefully designed to be representative of Canadian for-profit establishments. Use of the establishment level of analysis allows for more precise measurement of the study variables than the corporate-wide measures that are often used in this kind of research. An additional strength is that the data base allows for longitudinal analysis, allowing us to examine the impact of profit 
sharing on employee earnings for a substantial period subsequent to profit sharing adoption.

A potential problem for all types of survey research is the reliability of the data collected. Gerhart et. al. (2000) have found reliability to be a major concern for survey data when it is collected from a single respondent, as is the case for the WES. However, this single respondent issue may not pose as much of a concern for the WES as for other surveys. First, the format of the WES is designed to enhance reliability of responses, through allowing for preparation by respondents but interviews for actual data collection. This procedure enables clarification of both questions and answers. In so doing, trained Statistics Canada interviewers are used, who have no vested interest in the particular outcomes of any studies based on the survey information.

Second, Gerhart et. al. (2000) note that establishment-level surveys are likely more reliable in studying HR practices than corporate-level surveys, because the units of analysis are smaller, managers are more familiar with HR practices because they are responsible for implementing them, and HR practices are more homogenous, and Gerhart, Wright, and McMahan (2000) do indeed find higher reliability at the plant than at the company level. Further research by Wright and his colleagues (2001) concluded that single-respondent surveys should use a single business or single location as its unit of analysis, as is true for the WES. As a result of its careful design and data collection procedures, the WES data base has been seen as an appropriate vehicle for research on human resource practices (Aydemir and Skuterud 2009; Mohr and Zoghi 2008; Zatzick and Iverson 2006). Given this, we believe that the results generated by our analysis are sufficiently well-founded to contribute to the debate on whether employee profit sharing is a practice that contributes to or detracts from the financial well-being of employees.

Finally, all empirical studies are bounded by their temporal, national, and institutional contexts. The period under study here was characterized by good economic conditions in 1999- 
2000, an economic meltdown in 2001, and gradually improving economic conditions after that until the end of our study period. The study took place in Canada, which is deemed a "liberal economy” rather than a “coordinated market economy” (Kalmi and Kauhanen 2008), and where cash-based profit sharing plans are the norm, rather than deferred profit sharing plans, which are the norm in various other countries, most notably the United States. Any of these factors may have influenced our results.

\section{Conclusions}

On average, employees in Canadian establishments that adopted profit sharing during 1999-2001 appeared to benefit from the introduction of profit sharing, in terms of both their cash real earnings growth and total real earnings growth, in the five-year span following introduction of profit sharing. This advantage was both statistically and practically significant, adding about 15 percentage points to real employee earnings growth over the five-year period, a period during which employee earnings growth was generally modest. However, we note that, although not achieving statistical significance, the three-year result (about 8 percentage points) was quite similar on an annualized basis to the five-year result, although in fact earnings growth was highly variable on an annual basis in profit sharing adopters. Overall, employees that benefited the most from profit sharing are those employed by establishments that paid above average compensation prior to adopting profit sharing. However, neither employees in establishments with more participatory practices, nor employees in smaller establishments, benefit any more from introduction of profit sharing than employees in other establishments.

In terms of motives for adoption, we believe that our results are most consistent with the human capital motive for profit sharing, as a pre-existing high-wage policy increased the relationship between profit sharing and employee earnings growth significantly (in the three-year 
term at least), while neither participatory practices nor firm size affected this relationship. These latter findings do not support the "worker behavior" argument. Nonetheless, we should note that even though combining participation with profit sharing may not enhance worker behavior, it is still possible that profit sharing alone does affect worker behavior in ways other than through worker participation.

However, we do find some support for the substitution motive, most notably among lowwage adopters of profit sharing, where the human capital argument may not apply. Among these adopters, the only thing that profit sharing seemed to achieve for employees in the first three years of adoption was to put more of their pay at risk—with no offsetting financial benefitsince their total earnings at the end of that period (2004) were no different than non-adopters. That said, we do note that over the longer term (four to five years) employees in low-wage adopters did seem to realize a financial benefit from profit sharing, consistent with the argument that employees with more pay at risk will eventually require higher total earnings to compensate them for this added risk.

Taking a broader perspective, there has been considerable debate in recent years about the extent to which employees actually benefit, in financial terms, from a variety of "highperformance” or "high-involvement” workplace practices (Handel and Levine 2004; Kalmi and Kauhanen 2008). Our study contributes empirically to this debate by providing substantial evidence that one of these practices—employee profit sharing—can and does deliver significant financial benefits to employees, at least over the longer (four to five years) term. At the same time, by making employee earnings more responsive to financial circumstances, employers may be able to better manage costs in poor economic times, thus rendering employee profit sharing a win-win proposition for both employees and employers. 


\section{REFERENCES}

Allen, Matthew R., and Patrick Wright. 2007. "Strategic Management and HRM." In The Oxford Handbook of Human Resource Management, edited by P. Boxall, J. Purcell, and P. Wright, pp. 88-107. Oxford: Oxford University Press.

Andrews, Martyn, Lutz Bellmann, Thorsten Schank, and Richard Upward. 2010. “The Impact of Financial Compensation on Workers’ Compensation.” Zeitschrift fur Arbeitsmarkt Forschun—Journal of Labor Market Research, Vol. 43, No. 1, pp. 72-89.

Aydemir, Abdurrahman, and Mikal Skuterud. 2008. “The Immigrant Wage Differential within and across Establishments.” Industrial and Labor Relations Review, Vol. 61, No. 3, pp. 334-352.

Azfar, Omar, and Stephan Danninger. 2001. "Profit Sharing, Employment Stability, and Wage Growth.” Industrial and Labor Relations Review, Vol. 54, pp. 619-630.

Belanger, Paul R., Paul-Andre Lapointe and Benoit Levesque. 2002. “Workplace Innovation and the Role of Institutions." In Work and Employment Relations in the High-Performance Workplace, edited by Gregor Murray, Jacques Belanger, and Paul-Andre Lapointe, pp. 150-180. London: Continuum.

Bell, D. Wallace, and Charles G. Hanson. 1987. Profit Sharing and Profitability: How Profit Sharing Promotes Business Success. London: Kogan Page.

Bell, Linda A., and David Neumark. 1993. "Lump Sum Payments and Profit Sharing Plans in the Union Sector of the United States Economy." Economic Journal, Vol. 103, pp. 602-619. Black, Sandra E., Lisa M. Lynch, and Anya Krivelyova. 2004. “How Workers Fare When Employers Innovate.” Industrial Relations, Vol. 43, No. 1, pp. 44-66.

Blasi, Joseph R., Richard B. Freeman, Christopher Mackin, and Douglas L. Kruse. 2010. “Creating a Bigger Pie? The Effects of Employee Ownership, Profit Sharing, and Stock 
Options on Workplace Performance.” In Shared Capitalism at Work: Employee Ownership, Profit and Gain Sharing, and Broad-Based Stock Options, edited by Douglas L. Kruse, Richard B. Freeman, and Joseph R. Blasi, pp. 139-166. Chicago: University of Chicago Press.

Coates, E. M. 1991. "Profit Sharing Today: Plans and Provisions." Monthly Labor Review, Vol. 114, No. 4, pp. 19-25.

Cohen, Jacob, Patricia Cohen, Stephen G. West, and Leona S. Aiken. 2002. Applied Multiple Regression/Correlation Analysis for the Behavioral Sciences, Third Edition. Philadelphia: Lawrence Erlbaum.

Delery, John E. 1998. "Issues of Fit in Strategic Human Resource Management: Implications for Research." Human Resource Management Review, Vol. 8, No. 3, pp. 289-309.

Delery, John E., and D. Harold Doty. 1996. "Modes of Theorizing in Strategic Human Resource Management: Tests of Universalistic, Contingency, and Configurational Performance Predictions." Academy of Management Journal, Vol. 39, No. 4, pp. 802-835.

Estrin, Saul, and Nicholas Wilson. 1989. Profit Sharing, the Marginal Cost of Labour and Employment Variability. University of Bradford, Management Centre.

Fitzroy, Felix, and Kornelius Kraft. 1986. "Profitability and Profit Sharing." Journal of Industrial Economics, Vol. 35, No. 2, pp. 113-130.

Forth, John, and Neil Millward. 2004. "High-Involvement Management and Pay in Britain.” Industrial Relations, Vol. 43, No. 1, pp. 98-119.

Gerhart, Barry, Patrick M. Wright, and Gary C. McMahan. 2000. "Measurement Error in Research on the Human Resources and Firm Performance Relationship: Further Evidence and Analysis." Personnel Psychology, Vol. 53, No. 4, pp. 855-872.

Gerhart, Barry, Patrick M. Wright, Gary C. McMahan, and Scott A. Snell. 2000. "Measurement 
Error in Research on the Human Resources and Firm Performance Relationship: How Much Error Is There and How Does It Influence Effect Size Estimates?" Personnel Psychology, Vol. 53, pp. 803-834.

Godard, John. 2004. “A Critical Assessment of the High-Performance Paradigm.” British Journal of Industrial Relations, Vol. 42, No. 2, pp. 349-378.

Handel, Michael J., and Maury Gittleman. 2004. "Is There a Wage Payoff to Innovative Work Practices?” Industrial Relations, Vol. 43, No. 1, pp. 67-97.

Handel, Michael J., and David I Levine. 2004. “Editors’ Introduction: The Effects of New Work Practices on Workers.” Industrial Relations, Vol. 43, No. 1, pp. 1-43.

Hart R. A., and O. Hubler. 1991. "Are Profit Shares and Wages Substitute or Complementary Forms of Compensation?" KYKLOS, Vol. 44, No. 2, pp. 221-231.

Jensen, Michael, and William Meckling. 1976. "Theory of the Firm: Managerial Behavior, Agency Costs, and Ownership Structure." Financial Economics, Vol. 3, pp. 305-360.

Jones, Derek C., Panu Kalmi, and Antti Kauhanen. 2010. “Teams, Incentive Pay, and Productive Efficiency: Evidence from a Food-Processing Plant.” Industrial and Labor Relations Review, Vol. 63, No. 4, pp. 606-626.

Kalmi, Panu, and Antti Kauhanen. 2008. "Workplace Innovations and Employee Outcomes: Evidence from Finland.” Industrial Relations, Vol. 47, No. 3, pp. 430-459.

Kalmi, Panu, Andrew Pendleton, and Erik Poutsma. 2005. “Financial Participation and Performance in Europe.” Human Resource Management Journal, Vol. 15, No. 4, pp. 5467.

Kandel, Eugene, and Edward Lazear. 1992. "Peer Pressure and Partnerships." Journal of Political Economy, Vol. 100, pp. 801-817.

Katz, Harry C., and Noah M. Meltz. 1991. "Profit Sharing and Auto Workers Earnings—The 
United States vs Canada." Relations industrielles/Industrial Relations, Vol. 46, No. 3, pp. $515-530$.

Kato, Takao, and Motohiro Morishima. 2003. “The Nature, Scope and Effects of Profit Sharing in Japan: Evidence from New Survey Data.” International Journal of Human Resource Management, Vol. 14, No. 6, pp. 942-955.

Kim, Seongsu. 1998. "Does Profit Sharing Increase Firm Profits?" Journal of Labor Research, Vol. 19, No. 2, pp. 351-370.

Kruse, Douglas L. 1993. Profit Sharing: Does It Make a Difference? Kalamazoo, MI: W.E. Upjohn Institute.

Kruse, Douglas L. 1996. "Why Do Firms Adopt Profit-Sharing and Employee Ownership Plans?" British Journal of Industrial Relations, Vol. 34, pp. 515-538.

Kruse, Douglas L., Richard B. Freeman, and Joseph R. Blasi. 2010. “Do Workers Gain by Sharing: Employee Outcomes under Employee Ownership, Profit Sharing, and BroadBased Stock Options.” In Shared Capitalism at Work: Employee Ownership, Profit and Gain Sharing, and Broad-Based Stock Options, edited by Douglas L. Kruse, Richard B. Freeman, and Joseph R. Blasi, pp. 257-290. Chicago: University of Chicago Press.

Lawler, Edward E. 1986. High-Involvement Management: Participative Strategies for Improving Organizational Effectiveness. San Francisco: Jossey-Bass.

Lawler, Edward E. 1992. The Ultimate Advantage: Creating the High-Involvement Organization. San Francisco: Jossey Bass.

Lawler, Edward E., Susan A. Mohrman, and Gerald E. Ledford. 1998. Strategies for High Performance Organizations. San Francisco: Jossey Bass.

Lazear, Edward P. 2000. "Performance Pay and Productivity." American Economic Review, Vol. 90, pp. 1346-1361. 
Levine, David I., and Laura D. Tyson. 1990. "Participation, Productivity, and the Firm’s Environment." In Paying for Productivity: A Look at the Evidence, edited by A. S. Blinder, pp. 15-94. Washington, DC: The Brookings Institution.

Long, Richard J. 1997. "Motives for Profit Sharing: A Study of Canadian Chief Executive Officers." Relations industrielles/Industrial Relations, Vol. 52, No. 4, pp. 712-733.

Long, Richard J. 2002. "Performance Pay in Canada." In Paying for Performance: An International Comparison, edited by M. Brown and J. S. Heywood, pp. 52-89. Armonk, NY: M. E. Sharpe.

Long, Richard J. 2010. Strategic Compensation in Canada. Toronto: Nelson Education.

Long, Richard J., and Tony Fang. 2007. “How Strategic Is Strategic Pay? The Case of Employee Profit-Sharing.” Proceedings of the Administrative Sciences Association of Canada Annual Meetings, Ottawa.

Long, Richard J., and John L. Shields. 2005. "Performance Pay in Canadian and Australian Firms: A Comparative Study." International Journal of Human Resource Management, Vol. 16, No. 10, pp. 1783-1811.

MacDuffie, John Paul. 1995. Human-Resource Bundles and Manufacturing Performance Organizational Logic and Flexible Production Systems in the World Auto Industry." Industrial and Labor Relations Review, Vol. 48, No. 2, pp. 197-221.

Magnan, Michel, and Sylvie St-Onge. 2005. "The Impact of Profit Sharing on the Performance of Financial Services Firms." Journal of Management Studies, Vol. 42, No. 4, pp. 761791.

McNabb, Robert, and Keith Whitfield. 2007. “The Impact of Varying Types of PerformanceRelated Pay and Employee Participation on Earnings.” International Journal of Human Resource Management, Vol. 18, No. 6, pp. 1004-1025. 
Mitchell, Daniel J. B., and Renae F. Broderick. 1991. "Flexible Systems in the American Context: History, Policy, Research, and Implications.” In Advances in Industrial and Labor Relations, edited by Donna Sockell, David Lewin, and David Lipski, pp. 95-149. Greenwich, CT: JAI Press.

Mitchell, Daniel J. B., David Lewin, and Edward E. Lawler. 1990. "Alternative Pay Systems, Firm Performance, and Productivity." In Paying for Productivity: A Look at the Evidence, edited by A. S. Blinder, pp. 15-94. Washington, DC: The Brookings Institution.

Mohr, Robert D. and Zoghi, Cindy. 2008. "High-Involvement Work Design and Job Satisfaction.” Industrial \& Labor Relations Review, Vol. 61, No. 3, pp. 275-296.

Olson, Mancur. 1971. The Logic of Collective Action. Cambridge: Harvard University Press.

Osterman, Paul. 2000. "Work Reorganization in an Era of Restructuring: Trends in Diffusion and Effects on Employee Welfare.” Industrial and Labor Relations Review, Vol. 53, No. 2, pp. 179-196.

Parent, Daniel. 2002. "Performance Pay in the United States: Its Determinants and Effects." In Paying for Performance: An International Comparison, edited by M. Brown and J. S. Heywood, pp. 17-51. Armonk, NY: M. E. Sharpe.

Pil, Frits K., and John Paul MacDuffie. 1996. "The Adoption of High-Involvement Work Practices." Industrial Relations, Vol. 35, No. 3, pp. 423-455.

Robinson, Andrew M., and Nicholas Wilson. 2006. “Employee Financial Participation and Productivity: An Empirical Reappraisal.” British Journal of Industrial Relations, Vol. 44, No. 1, pp. 31-50.

Statistics Canada. 2004. Workplace and Employee Survey Compendium: 2001. Ottawa: Statistics Canada.

Statistics Canada. 2006. Guide to the Analysis of the Workplace and Employee Survey: 2003. 
Ottawa: Statistics Canada.

Strauss, George. 1990. "Participatory and Gain Sharing Systems: History and Hope." In Profit Sharing and Gain Sharing, edited by M. J. Roomkin, pp. 1-45. Metuchen, NJ: Scarecrow Press.

Tyson, David E. 1996. Profit Sharing in Canada. Toronto: John Wiley and Sons.

Usalcas, Jeannine. 2008. “Hours Polarization Revisited.” Perspectives on Labour and Income, Vol. 20, No. 2 (March 2008) pp. 5-15.

US Chamber of Commerce. 1989. Employee Benefits. Washington, D.C.: Economic Policy Division, Chamber of Commerce of the United States.

Wadhwani, Sushil, and Martin Wall. 1990. "The Effects of Profit Sharing on Employment, Wages, Stock Returns, and Productivity: Evidence from UK Microdata." Economic Journal, Vol. 100, pp. 1-17.

Weitzman, Martin L. 1984. The Share Economy. Cambridge, MA: Harvard University Press.

Weitzman, Martin L., and Douglas L. Kruse. 1990. “Profit Sharing and Productivity.” In Paying for Productivity: A Look at the Evidence, edited by Alan S. Blinder, pp. 95-142. Washington, DC: The Brookings Institution.

Wright, Patrick M., Timothy M. Gardner, Lisa M. Moynihan, Hyeon Jeong Park, Barry Gerhart, and John E. Delery. 2001. "Measurement Error in Research on Human Resources and Firm Performance: Additional Data and Suggestions for Future Research." Personnel Psychology, Vol. 54, No. 4, pp. 875-901.

Zatzick, Christopher D., and Roderick D. Iverson. 2006. "High Involvement Management and Workforce Reduction: Competitive Advantage or Disadvantage?" Academy of Management Journal, Vol. 49, No. 5, pp. 999-1015. 


\section{Table 1}

\section{Means, Standard Deviations, and Correlations ${ }^{a}$}

\begin{tabular}{|c|c|c|c|c|c|c|c|c|c|c|c|c|}
\hline Variable & Mean & s.d. & 1 & 2 & 3 & 4 & 5 & 6 & 7 & 8 & 9 & 10 \\
\hline 1. Profit Sharing Adoption & .14 & .35 & - & & & & & & & & & \\
\hline 2. Participation Index & 1.24 & 1.42 & $.19 * * *$ & - & & & & & & & & \\
\hline 3. Union Density & .22 & .35 & $-.10 * * *$ & $.09 * * *$ & - & & & & & & & \\
\hline 4. Establishment Size (00’s of emps.) & .45 & .13 & .03 & $.11^{* *}$ & $.12^{* * *}$ & - & & & & & & \\
\hline 5. Cash Emp. Earnings 2001 (\$000’s) & 40.58 & 22.53 & $.11^{* * *}$ & -.03 & .03 & .03 & - & & & & & \\
\hline 6. Total Emp. Earnings 2001 (\$000’s) & 43.20 & 24.06 & $.09 * *$ & -.02 & .02 & $.04^{*}$ & $.98 * * *$ & - & & & & \\
\hline 7. Individual Incentives & .44 & .50 & $.20 * * *$ & $.15^{* * *}$ & $-.06 * * *$ & $.05^{* *}$ & $.08 * * *$ & $.09 * * *$ & - & & & \\
\hline 8. Merit Pay & .31 & .46 & $.08^{* * *}$ & $.04^{*}$ & -.02 & $.08 * * *$ & -.01 & -.00 & $.36 * * *$ & - & & \\
\hline 9. Gain Sharing & .20 & .40 & $.17 * * *$ & $.15^{* * *}$ & .03 & .03 & .01 & .01 & $.33 * * *$ & $.10 * * *$ & - & \\
\hline 10. Employee Stock Plan & .11 & .32 & $.09 * * *$ & $.18 * * *$ & $.11^{* * *}$ & $.09 * * *$ & .01 & .02 & $.29 * * *$ & $.31 * * *$ & $.21 * * *$ & - \\
\hline 11. Cash Earnings Growth 2001-04 & .10 & .52 & .01 & $-.07 * * *$ & .01 & -.01 & $-.29 * * *$ & $-.30 * * *$ & $.04^{*}$ & .04 & .01 & $.10^{* * *}$ \\
\hline 12. Total Earnings Growth 2001-04 & .11 & .53 & .02 & $-.07 * * *$ & .02 & .01 & $-.30 * * *$ & $-.30 * * *$ & .04 & .03 & .01 & $.10^{* * *}$ \\
\hline 13. Cash Earnings Growth 2001-06 & .11 & .50 & $.07 * * *$ & .01 & -.02 & .02 & $-.33^{* * *}$ & $-.31 * * *$ & .04 & $.06^{* *}$ & -.01 & $.06 * *$ \\
\hline 14. Total Earnings Growth 2001-06 & .12 & .50 & $.08^{* * *}$ & .01 & -.01 & .03 & $-.35^{* * *}$ & $-.33 * * *$ & .03 & .06 & .01 & .01 \\
\hline
\end{tabular}

${ }^{\mathrm{a}} n=1,717 .{ }^{*} \mathrm{p}<.10 ;{ }^{* *} \mathrm{p}<.05 ;{ }^{* * *} \mathrm{p}<.01$; two tailed tests. 


\section{Table 2}

\section{Multiple Regressions Predicting Employee Earnings Growth ${ }^{\mathrm{a}}$}

\begin{tabular}{|l|c|c|c|c|}
\hline \multirow{2}{*}{ Variable } & \multicolumn{2}{|c|}{ Growth in Real Cash Earnings } & \multicolumn{2}{c|}{ Growth in Real Total Earnings } \\
\cline { 2 - 5 } & $2001-2004$ & $2001-2006$ & $2001-2004$ & $2001-2006$ \\
\hline Constant & $.236^{* * *}(.078)$ & $.260^{* * *}(.084)$ & $.237^{* * *}(.074)$ & $.263^{* * *}(.080)$ \\
\hline Performance Pay Controls & & & & \\
\hline Individual Incentives & $.082^{*}(.044)$ & $.043(.048)$ & $.083^{*}(.045)$ & $.043(.049)$ \\
\hline Merit Pay & $-.011(.052)$ & $.029(.059)$ & $-.019(.053)$ & $.028(.060)$ \\
\hline Gain Sharing & $-.057(.055)$ & $-.050(.052)$ & $-.052(.055)$ & $-.042(.052)$ \\
\hline Employee Stock Plan & $.148^{*}(.078)$ & $.055(.083)$ & $.145^{*}(.083)$ & $.053(.089)$ \\
\hline Establishment Controls & & & & \\
\hline Participation Index & $-.039^{*}(.021)$ & $-.012(.021)$ & $-.036^{*}(.021)$ & $-.008(.021)$ \\
\hline Union Density & $.038(.073)$ & $-.018(.063)$ & $.068(.077)$ & $.016(.064)$ \\
\hline Establishment Size $(00 ’ s)$ & $.005(.007)$ & $.013^{*}(.007)$ & $.007(.008)$ & $.016^{* *}(.008)$ \\
\hline Employee Earnings $2001^{\mathrm{b}}\left(\$ 000^{\prime} \mathrm{s}\right)$ & $-.008^{* * *}(.002)$ & $-.008^{* * *}(.002)$ & $-.007^{* * *}(.001)$ & $-.008^{* * *}(.001)$ \\
\hline Profit Sharing Adoption & $.076(.058)$ & $.146^{* *}(.067)$ & $.083(.058)$ & $.155^{* *}(.067)$ \\
\hline & & & & \\
\hline Cases & 1717 & 1566 & 1717 & 1566 \\
\hline$R^{2}$ & $.142^{* * *}$ & $.163^{* * *}$ & $.145^{* * *}$ & $.171^{* * *}$ \\
\hline
\end{tabular}

${ }^{*} \mathrm{p}<.10 ; * * \mathrm{p}<.05 ; * * * \mathrm{p}<.01 ;$ two tailed tests.

${ }^{\mathrm{a}}$ OLS specification (unstandardized regression coefficients) for both specifications. Standard errors in brackets.

${ }^{\mathrm{b}}$ Cash Earnings 2001 used for regressions predicting Growth in Real Cash Earnings, and Total Earnings 2001 used in regressions predicting Growth in Real Total Earnings. 


\section{Table 3}

\section{Multiple Regressions Predicting Employee Earnings Growth ${ }^{\mathrm{a}}$ Including Interaction Terms}

\begin{tabular}{|l|c|c|c|c|}
\hline \multirow{2}{*}{ Variable } & \multicolumn{2}{|c|}{ Growth in Real Cash Earnings } & \multicolumn{2}{c|}{ Growth in Real Total Earnings } \\
\cline { 2 - 5 } & $2001-2004$ & $2001-2006$ & $2001-2004$ & $2001-2006$ \\
\hline Performance Pay Controls & & & & \\
\hline Individual Incentives & $.097^{* *}(.044)$ & $.055(.047)$ & $.036(.040)$ & $.052(.048)$ \\
\hline Merit Pay & $-.020(.052)$ & $.022(.058)$ & $.047(.042)$ & $.021(.060)$ \\
\hline Gain Sharing & $-.054(.0550$ & $-.043(.052)$ & $.053(.045)$ & $-.037(.052)$ \\
\hline Employee Stock Plan & $.147^{*}(.082)$ & $.072(.086)$ & $.024(.051)$ & $.067(.091)$ \\
\hline Establishment Controls & & & & \\
\hline Participation Index & $-.039^{*}(.022)$ & $-.014(.022)$ & $-.027^{* *}(.012)$ & $-.009(.022)$ \\
\hline Union Density & $.038(.077)$ & $-.001(.066)$ & $.037(.054)$ & $.029(.066)$ \\
\hline Establishment Size $\left(00^{\prime}\right.$ 's) & $.008(.010)$ & $.017^{*}(.009)$ & $.003(.006)$ & $.021^{* *}(.010)$ \\
\hline Employee Earnings 2001 $\left.{ }^{\mathrm{b}}\left(\$ 000^{\prime}\right)^{\prime}\right)$ & $-.010^{* * *}(.001)$ & $-.010^{* * *}(.002)$ & $-.005^{* * *}(.007)$ & $-.009^{* * *}(.001)$ \\
\hline Profit Sharing Adoption & $.061(.059)$ & $.114(.077)$ & $.110^{*}(.058)$ & $.129^{*}(.078)$ \\
\hline Interaction Terms & & & & \\
\hline PS X Participation & $.015(.031)$ & $.016(.031)$ & $.004(.027)$ & $.013(.031)$ \\
\hline PS X Size & $-.009(.015)$ & $-.013(.012)$ & $-.004(1.009)$ & $.015(.014)$ \\
\hline PS X Earnings & $.005^{* *}(.002)$ & $.004(.003)$ & $.003^{* * *}(.010)$ & $.003(.003)$ \\
\hline & & & & \\
\hline Cases & 1717 & 1566 & 1717 & 1566 \\
\hline$R^{2}$ & $.152^{* * *}$ & $.172^{* * *}$ & $.049^{* * *}$ & $.177^{* * *}$ \\
\hline
\end{tabular}

${ }^{*} \mathrm{p}<.10 ; * * \mathrm{p}<.05 ; * * * \mathrm{p}<.01 ;$ two tailed tests.

${ }^{a}$ OLS specification (unstandardized regression coefficients) for both specifications. Standard errors in brackets.

${ }^{\mathrm{b}}$ Cash Earnings 2001 used for regressions predicting Growth in Real Cash Earnings, and Total Earnings 2001 used in regressions predicting Growth in Real Total Earnings. 


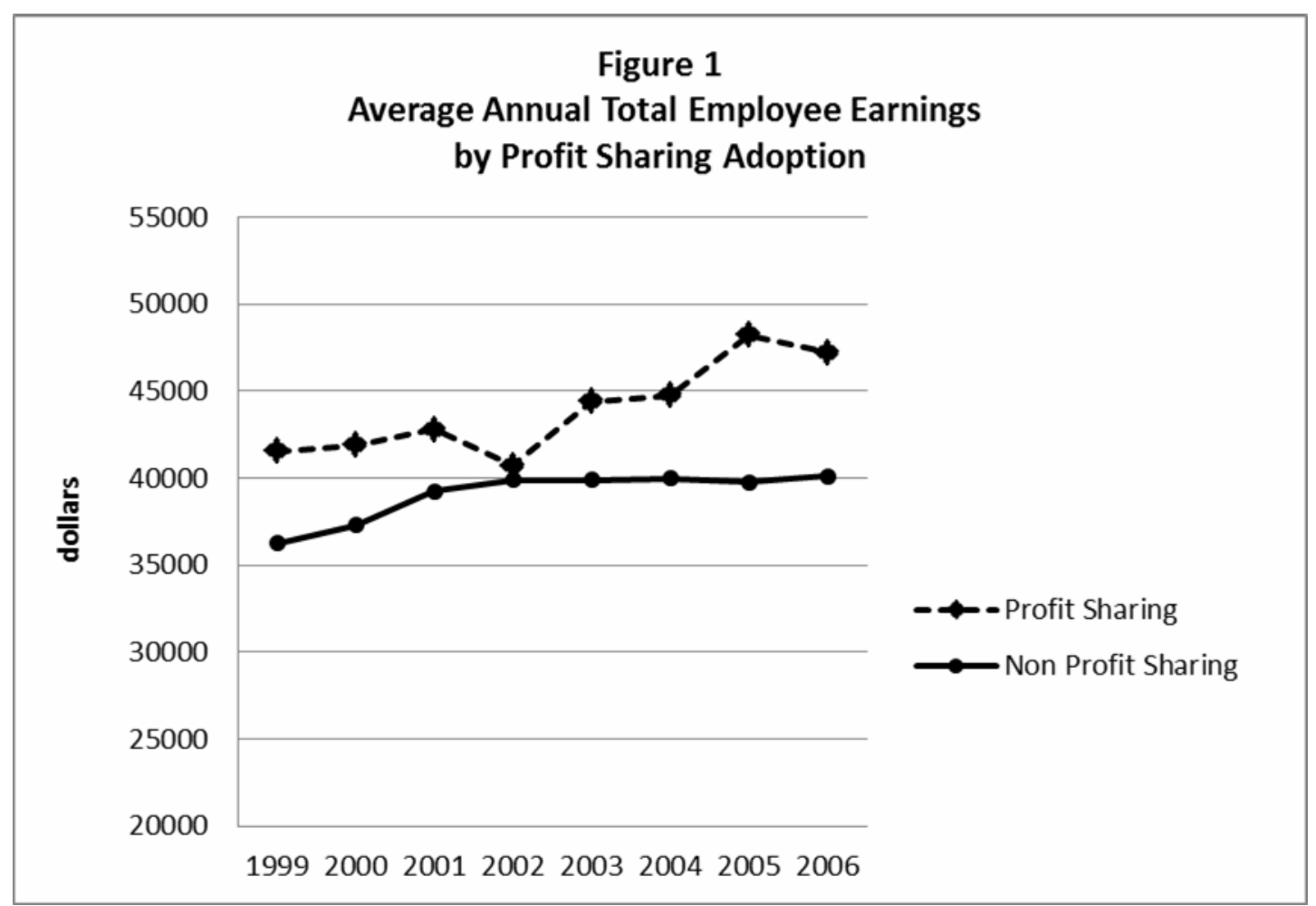




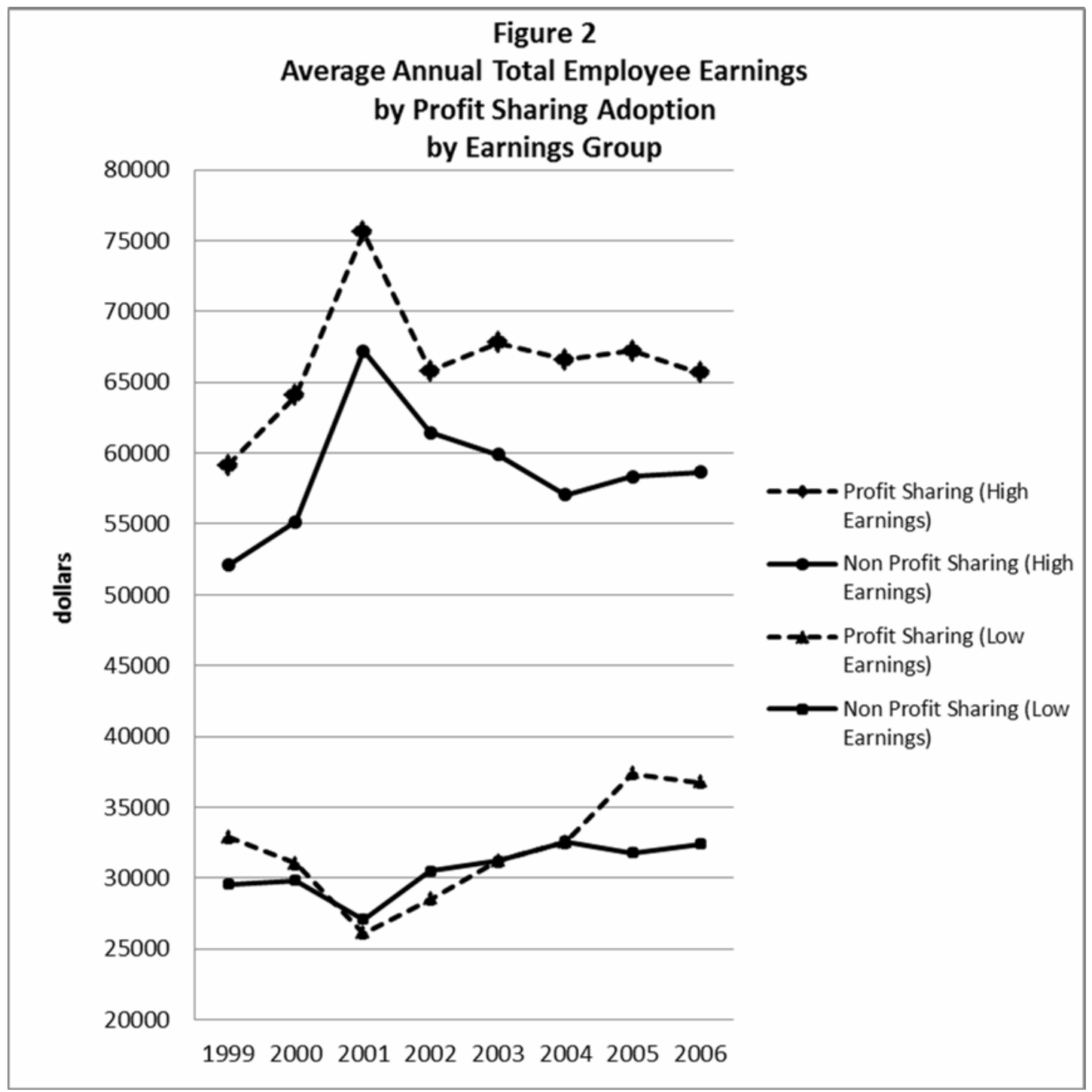

